\title{
Література:
}

1. Техніко-криміналістичне дослідження документів : навч. посіб. / [авт. кол. : О. В. Воробей, А. В. Кофанов]. - К. : Нац. акад. внутр. справ, 2011. - С. 204-209.

2. Біленчук П.Д. Криміналістика: Підручник. / П.Д. Біленчук, В.К. Лисиченко, Н.І. Клименко // Атіка. - К. - 2001. - С. 171.

3. Воробей О.В. Методика судово-технічної експертизи документів (загальна частина) / О.В. Воробей // Затверджено на засіданні КМР ДНДЕКЦ МВС України Протокол № 15 від 27.04. 2006. - К. - 2006. С. 245.

4. Encyclopedia of Library and Information Science / Ed. by M. J. Bates, M. N. Maack and M. A. Drake. - 2nd edn. - Marcel Dekker, 2003. - C. 22-88.

DOI https://doi.org/10.30525/978-9934-588-92-1-88

\section{FORENSIC RECOMMENDATIONS FOR THE PRE-TRIAL INVESTIGATION AS A MEANS OF ENSURING THE ACCESS TO A FAIR TRIAL IN CRIMINAL PROCEEDINGS}

\author{
Kovalenko A. V. \\ PhD in Law, \\ Associate Professor at the Chair of Criminal-Law Disciplines \\ Luhansk State University of Internal Affairs named after E. O. Didorenko \\ Sievierodonetsk, Luhansk region, Ukraine
}

Bringing a person to criminal justice is an excessive and very responsible activity. Any mistake by the authorities can lead to the punishment of innocent people, criminals will avoid responsibility and continue to harm society. As a result, criminal procedure is very carefully regulated, and the requirements and standards for criminal prosecution are clearly established by both national and international law.

The current Criminal Procedure Code of Ukraine includes the tasks of criminal proceeding to ensure prompt, complete and impartial investigation and trial so that everyone who has committed a criminal offense is prosecuted to the extent of his guilt, no innocent person has been accused or convicted, no person has been subjected to unreasonable procedural coercion and that proper legal procedure has been applied to each participant in the 
criminal proceeding. These provisions correspond to Article 6 of the Convention for the Protection of Human Rights and Fundamental Freedoms. According to the article, in the determination of any criminal charge against him is entitled to a fair and public hearing within a reasonable time by an independent and impartial tribunal established by law, which will establish the validity of any criminal charges against him.

In the context of the case law of the European Court of Human Rights, the practice of national courts of Ukraine, prompt and effective pre-trial investigation is an essential guarantee of the effectiveness of criminal proceedings in general and a necessary condition for ensuring public access to justice in criminal cases.

Thus, in the judgment in Zorina and Others v. Ukraine, the ECtHR formulates some criteria for the effectiveness of a pre-trial investigation, including: the appropriateness of investigative actions, the promptness and reasonable speed of the investigation, the involvement of the victim's family, and the independence of the investigation. Another such criterion is the thoroughness of the investigation, which is that public authorities should take all appropriate and available measures to ensure the collection of evidence on events, including, inter alia, witness statements and forensic examinations.

Thus, it can be concluded that strict compliance by the authorized persons with the requirements of the procedural law is not enough to conduct an effective and prompt pre-trial investigation, gather sufficient evidence and build an effective line of prosecution against the offender. The overall effectiveness of the pre-trial investigation requires the professionalism of the authorized persons, their high moral level and personal motivation.

Specific guarantees of effective investigator's activity are his ability to act in conditions of low amount of information about the event of the offense at the initial stage of pre-trial investigation, proper use of special technical means to detect and record traces of criminal offense, competence in conducting public and covert investigative (search) actions, successful tactical risk management, the ability to organize interaction with other authorized units, knowledge of the specifics of the investigation of certain types of criminal offenses, the ability to correctly determine the general directions and specific strategy of the investigation in each case, etc.

The investigator begins to acquire all these specific skills at the stage of studying forensic science during higher education. Such skills are improved in the course of his practical activity through self-learning and accumulation of empirical experience. Therefore, it is crucial that practitioners have access to modern, well-founded, practical-oriented forensic recommendations 
developed by scientists for the pre-trial investigation of criminal offenses at each stage of the formation of their professional consciousness.

Recommendations of a technical nature allow the most effective use of forensic techniques to detect, record and study the reflections that the offender leaves in the external environment. Tactical recommendations allow the investigator to conduct investigative (search) actions in the most tactful way in order to obtain new and verify already obtained evidence in criminal proceedings. Forensic recommendations of a methodological nature allow to choose the right strategy of investigation, to determine the order and priority of investigative (search) actions and organizational measures, etc. Finally, it should be noted that such recommendations are of particular value provided they are comprehensive and logically structured.

Thus, the availability of professionally developed and practically oriented forensic recommendations for pre-trial investigation is one of the necessary conditions for ensuring the effectiveness of pre-trial investigation and access of individuals to fast and efficient justice in criminal proceedings.

DOI https://doi.org/10.30525/978-9934-588-92-1-89

\title{
ДО ПИТАННЯ ВИЗНАЧЕННЯ ПОНЯТТЯ ЕФЕКТИВНОСТІ ДОСУДОВОГО РОЗСЛІДУВАННЯ
}

\author{
Корчева Т. В. \\ кандидат юридичних наук, \\ асистент кафедри кримінального процесу \\ Національного юридичного університету імені Ярослава Мудрого \\ м. Харків, Україна
}

Кримінальний процесуальний кодекс України (далі КПК України) у ст.ст. 36, 38-40 закріплює одним з обов'язків суб'єктів, які ведуть досудове розслідування (прокурора, керівника органу досудового розслідування, слідчого) забезпечення ефективності досудового розслідування [1]. Але, у КПК України визначення терміна «ефективність», що вживається на позначення обов'язку у процесуальної діяльності вищевказаних суб'єктів, відсутнє. Разом із тим, варто зазначити, що невиконання вказаного обов'язку тягне певні процесуальні наслідки. Так, керівником органу прокуратури, через неефективне здійснення прокурором нагляду за дотриманням законів 